Vol. 2 | No. 4 | 2021 | Hal. 348-354

\title{
PENINGKATAN AWARENESS MASYARAKAT TERHADAP PENTINGNYA PENERAPAN PROTOKOL KESEHATAN 5M SEBAGAI MITIGASI PENYEBARAN COVID-19 DI DESA WATUREJO KECAMATAN NGANTANG
}

\author{
Erfan Efendi, Muhammad Shofyan Tsauri, Ayu Mei Lisa Putri, Lutfi Damayanti, \\ Khoirotul Kiptiyah, Anita Febriana, Siti Nurhalisa, Hendri Kurniawan, Mohammad \\ Safi'in, Dilyan Ardi Hutama, Eka Hariyanto \\ Fakultas Ekonomi dan Bisnis, Universitas Islam Malang \\ *korespondensi email: erfanefendi@unisma.ac.id
}

\begin{abstract}
ABSTRAK
Pandemi COVID-19 ini telah menyebabkan masalah serius pada dunia kesehatan global yang berdampak besar terhadap sudut pandang orang menginterpretasikan dunia dalam kegiatan kehidupan sehari-hari. Pemerintah juga turut dalam upaya pencegahan penyebaran virus COVID-19 seperti pemberlakuan pebatasan sosial dan imbauan penerapan Protokol Kesehatan 5M, yaitu memakai masker, mencuci tangan, menjaga jarak, menghindari kerumunan, serta mengurangi mobilitas.Beberapa masyarakat di Desa Waturejo, Kecamatan Ngantang, Kabupaten Malang kurang peduli pada penerapan protokol kesehatan dan penerapan hidup sehat. Kurangnya kepedulian dan pelaksanaan protokol kesehatan ini akibat kurangnya edukasi yang diterima masyarakat akan pentingnya protokol kesehatan dan hidup sehat untuk mencegah penyebaran COVID-19 yang bisa dibilang masih cukup tinggi dan perlu diwaspadai. Sehingga diperlukan sosialisasi demi meningkatkan awareness masyarakat terhadap pentingnya penerapan Protokol Kesehatan dan hidup sehat di era pandemi COVID-19 seperti saat ini. Tujuan diadakannya kegiatan sosialisasi ini sebagai upaya menurunkan tingkat penyebaran COVID-19, yakni dengan memberikan wawasan serta edukasi pada warga Desa Waturejo, Kecamatan Ngantang, Kabupaten Malang mengenai pentingnya Protokol Kesehatan dan hidup sehat di tengah masa pandemi COVID-19. Metode yang digunakan dalam kegiatan ini yakni metode partisipatif, dengan beberapa tahapan kegiatan, yaitu : (1) tahapan awal yaitu mengenai sosialisasi yang akan dilakukan dengan penyusunan jadwal penyampaian materi, distribusi kegiatan pada anggota tim, serta materi presentasi; (2) tahapan kedua, merupakan tahap penyampaian sosialisasi yang dipresentasikan langsung melalui power point ; (3) tahapan ketiga, berisi tahap evaluasi dari materi sosialisasi yang telah dipresentasikan dengan kegiatan tanya jawab yang berasal dari peserta yang mengikuti kegiatan sosialisasi; (4) Tahapan keempat, berisi kegiatan pembagian masker yang sesuai dengan Standar Nasional Indonesia (SNI) dan hand sanitizer kepada peserta kegiatan; (5) Tahap kelima yaitu tahap pemasangan banner tentang pentingnya protokol kesehatan Kegiatan pengabdian masyarakat ini berjalan dengan lancar dan disambut antusiasme warga. Sehingga kesimpulan yang dapat diambil,
\end{abstract}


yaitu bahwa sosialisasi menggunakan metode partisipatif lebih efektif dan efisien dalam penyampaiannya kepada masyarakat.

Kata Kunci: covid-19; protokol kesehatan; hidup sehat

\section{PENDAHULUAN}

Severe Acute Respiratory Syndrome Coronavirus 2 (SARS-CoV-2) merupakan coronavirus jenis baru yang awal mulanya muncul di Wuhan, China. Virus ini dapat menyebabkan penyakit baik pada hewan maupun manusia. Pada manusia virus ini menyerang saluran pernafasan seperti flu ringan hingga dapat menyebabkan penyakit dengan gejala berat yakni Middle East Respiratiry Syndrome (MERS) dan Severe Acute Respiratory Syndrome (SARS). Jika terinfeksi virus ini maka tanda dan gejala umum yang terjadi yaitu gangguan pernafasan akut seperti batuk, demam, dan sesak nafas (Kemenkes RI, 2020). Namun pada sebagian kasus yang berkembang menjadi komlikasi berat seperti kegagalan organ, syok septik, edema paru, pneumonia berat, serta sindrom pernafasan akut lainnya (Chen, et al., 2020).

Berdasarkan data dari Tim Komunikasi Komite Penanganan Corona Virus Disease 2019 (COVID-19) dan Pemulihan Ekonomi Nasional (KPCPEN) situasi COVID-19 di Indonesia saat ini sejak kasus pertama hingga tanggal 22 September 2021 jumlah pasien terkonfirmasi positif tercatat 4.192.695 kasus dan pemberian vaksin sebanyak 124.882 .412 dosis (KPCPEN, 2021).

Pandemi COVID-19 ini telah menyebabkan masalah serius pada dunia kesehatan global yang berdampak besar terhadap sudut pandang orang menginterpretasikan dunia dalam kegiatan sehari-hari. Pemerintah juga turut dalam upaya pencegahan penyebaran virus COVID-19 seperti pemberlakuan pebatasan sosial dan imbauan penerapan Protokol Kesehatan 5M, yaitu memakai masker, mencuci tangan, menjaga jarak, menghindari kerumunan, serta mengurangi mobilitas.

Beberapa masyarakat di Desa Waturejo, Kecamatan Ngantang, Kabupaten Malang kurang peduli pada penerapan protokol kesehatan dan penerapan hidup sehat. Kurangnya kepedulian dan pelaksanaan protokol kesehatan ini akibat kurangnya edukasi yang diterima masyarakat akan pentingnya protokol kesehatan dan hidup sehat untuk mencegah penyebaran COVID-19 yang bisa dibilang masih cukup tinggi dan perlu diwaspadai. Sebagian masyarakat juga kurang peduli terhadap penggunaan masker dan hand sanitizer disetiap kegiatan yang dilakukan. Oleh karena itu, perlu diadakannya sosialisasi untuk meningkatkan pemahaman masyarakat akan pentingnya penerapan protokol kesehatan dan hidup sehat di tengah pandemi COVID-19. Sehingga diperlukan sosialisasi demi meningkatkan awareness masyarakat terhadap pentingnya penerapan Protokol Kesehatan dan hidup sehat di era pandemi COVID-19 seperti saat ini. Berdasarkan uaraian latar belakang tersebut, maka dilaksanakanlah sosialisasi tentang pentingnya penerapan Protokol Kesehatan dan hidup sehat di era pandemic COVID-19. Dengan dilaksanakannya kegiatan sosialisasi ini diharapkan warga dapat lebih mewaspadai bahayanya COVID-19 dan meningkatkan awareness terhadap Protokol Kesehatan dan hidup sehat saat tingkat penyebaran COVID-19 masih bisa dikatakan cukup tinggi saat ini.

Tujuan diadakannya kegiatan sosialisasi ini sebagai upaya menurunkan tingkat penyebaran COVID-19, yakni dengan memberikan wawasan serta edukasi pada warga Desa Waturejo, Kecamatan Ngantang, Kabupaten Malang mengenai pentingnya Protokol Kesehatan dan hidup sehat di tengah masa pandemi COVID-19. 


\section{METODE}

Penggunaan metode dalam kegiatan ini adalah metode partisipatif. Metode partisipatif merupakan metode pendampingan yang bertujuan untuk memberdayakan kelompok masyarakat atau kelompok mitra dalam menyelesaikan permasalahan (Ilsan, Salim, \& Husain, 2020). Kegiatan ini dilaksanakan mulai tanggal 31 Agustus 2021 sampai dengan 01 September 2021. Pihak yang terkait dalam kegiatan ini yaitu masyarakat Desa Waturejo, Kecamatan Ngantang, Kabupaten Malang. Bentuk kegiatan yang dilakukan adalah penyuluhan dan evaluasi. Berdasarkan bentuk kegiatan diatas, terdapat beberapa rincian kegiatan yang dilakukan, diantaranya adalah:

1. Tahapan awal, yaitu tahap awal mengenai sosialisasi yang akan dilakukan dengan penyusunan jadwal penyampaian materi, distribusi kegiatan pada anggota tim, serta materi presentasi, yang nantinya akan langsung dipresentasikan oleh pemateri melalui media power poin;

2. Tahapan kedua, merupakan tahap penyampaian sosialisasi yang dipresentasikan langsung melalui power point;

3. Tahapan ketiga, berisi tahap evaluasi dari materi sosialisasi yang telah dipresentasikan dengan kegiatan tanya jawab yang berasal dari peserta yang mengikuti kegiatan sosialisasi;

4. Tahapan keempat, berisi kegiatan pembagian masker yang sesuai dengan Standar Nasional Indonesia (SNI) dan hand sanitizer kepada peserta kegiatan;

5. Tahapan kelima, yaitu tahap pemasangan banner tentang pentingnya protokol kesehatan.

\section{HASIL DAN PEMBAHASAN}

Proses transmisi SARS-CoV-2 yang melalui pertikel yang ada di udara (aerosol) serta virus yang bertahan di udara (airborne) mengakibatkan masih banyaknya kasus positif terjangkit COVID-19. Oleh karena itu, baik pemerintah Indonesia maupun dari organisasi kesehatan dunia (WHO) mengimbau masyarakat untuk tetap mewaspadai transmisi dari virus COVID-19 ini serta terus menyuarakan akan penerapan Protokol Kesehatan (ProKes) $5 \mathrm{M}$.

Saat ini, pemerintah Indonesia terus menyerukan tentang pentingnya penerapan Protokol Kesehatan 5M demi kondusifnya kasus terinfeksi virus COVID-19. Pelaksanaan kegiatan sosialisasi pada masyarakat ini juga menyesuaikan dengan imbauan dari pemerintah betapa pentingnya penerapan ProKes dan hidup sehat di tengah pandemi COVID-19 ini.

Sosialisasi di Desa Waturejo, Kecamatan Ngantang, Kabupaten Malang mengenai pentingnya penerapan protokol kesehatan dan hidup sehat di era pandemi COVID-19 dapat terlaksana dengan lancar dan disambut oleh antusiasme warga sekitar. Antusiasme warga nampak dari feedback yang diberikan, seperti fokus selama penyampaian materi sosialisasi dan penyampaian pertanyaan kepada pemateri. Selain itu, feedback yang warga berikan merupakan suatu indikasi bahwa warga sudah mulai memahami materi yang disampaikan oleh pemateri, yakni mengenai Protokol Kesehatan 5M dan penerapan hidup sehat di tengah masa pandemi Covid-19. Atas terlaksananya kegiatan sosialisasi ini diharapkan warga dapat menerapkan semua hal tersebut di masa PPKM ini. Selain kegiatan sosialisasi kami juga mengadakan kegiatan pembagian masker dan hand sanitizer sebagai bentuk upaya patuh terhadap Protokol Kesehatan yang saat ini berlaku di Desa Waturejo, Kecamatan Ngantang, Kabupaten Malang. Berikut beberapa dokumentasi dari seluruh rangkaian tahapan serta kegiatan dalam pelaksanaan sosialisasi ini.

\section{Persiapan Sosialisasi}


Pada tahap ini, hal pertama yang dilakukan yaitu penyusunan jadwal penyampaian materi sosialisasi, distribusi kegiatan pada anggota tim, serta materi presentasi, yang nantinya akan langsung dipresentasikan oleh pemateri melalui media power point.

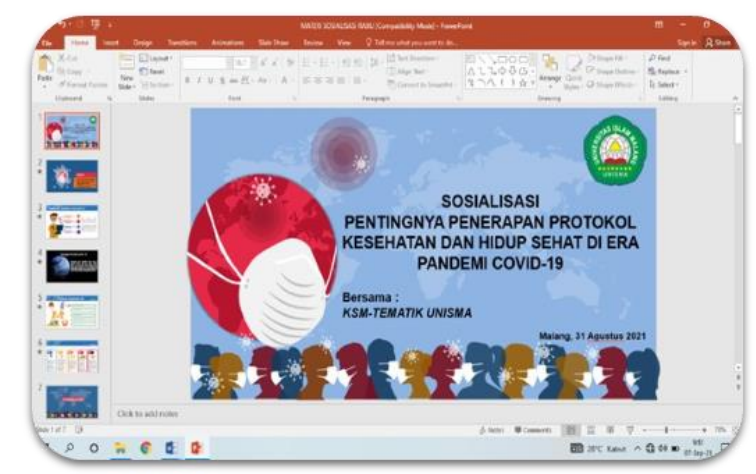

Gambar 1. Materi Sosialisasi

(Sumber: Dok. KSM-Tematik Kelompok 07)

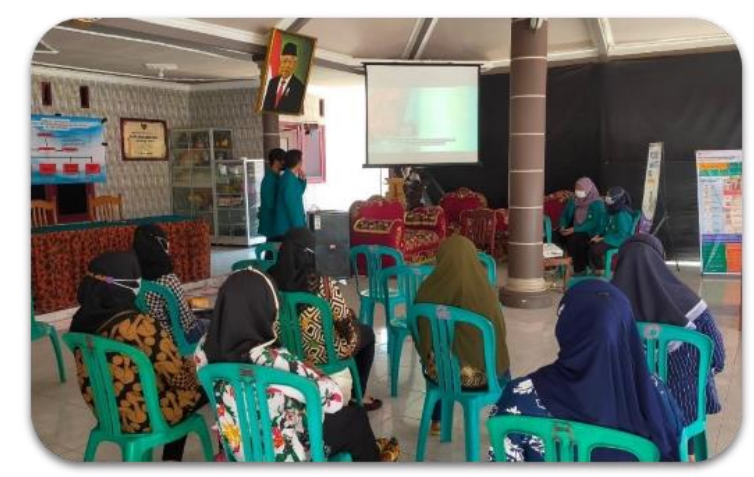

Gambar 2. Video Edukasi

(Sumber: Dok. KSM-Tematik Kelompok 07)

\section{Tahap Sosialisasi}

Pada tahap ini, dilakukan sosialisasi secara langsung menggunakan media presentasi powerpoint.

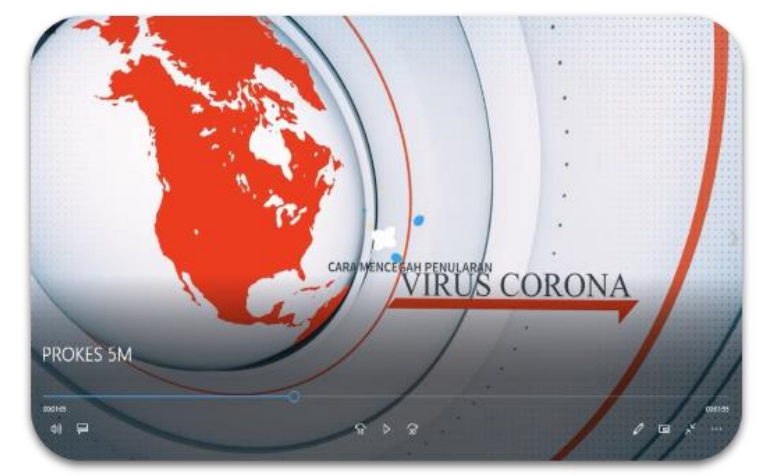

Gambar 3. Kegiatan Sosialisasi

(Sumber: Dok. KSM-Tematik Kelompok 07)

\section{Tahap Evaluasi}

Pada tahap ini dilakukan tanya jawab dengan peserta sosialisasi. 


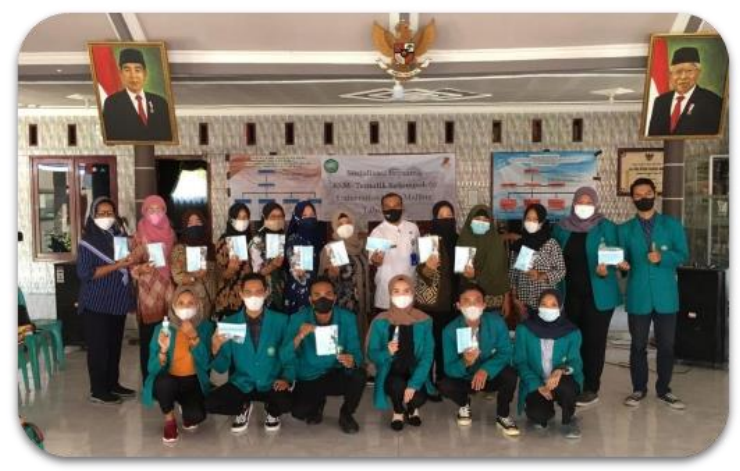

Gambar 4. Kegiatan Evaluasi

(Sumber: Dok. KSM-Tematik Kelompok 07)

\section{Tahap Pembagian Masker dan Hand Sanitizer}

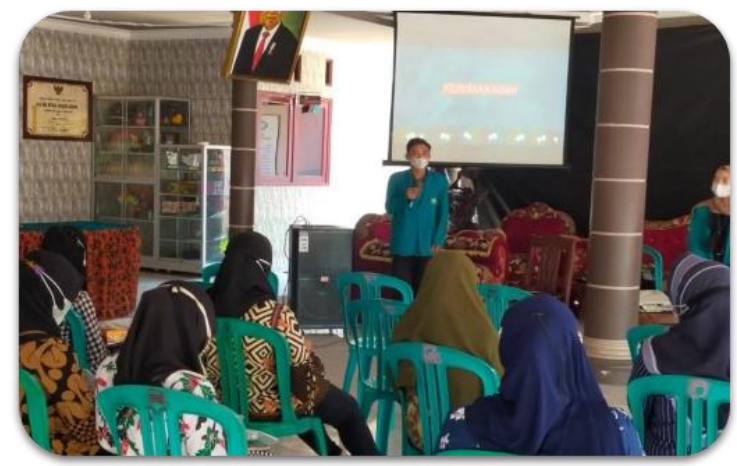

Gambar 5. Kegiatan Pembagaian Masker dan Hand Sanitizer (Sumber: Dok. KSM-Tematik Kelompok 07)

\section{Tahap Pemasangan Banner}

Tahap ini dilakukan di dua lokasi, yaitu di Dusun Sumbergondo dan di Balai Desa Waturejo.

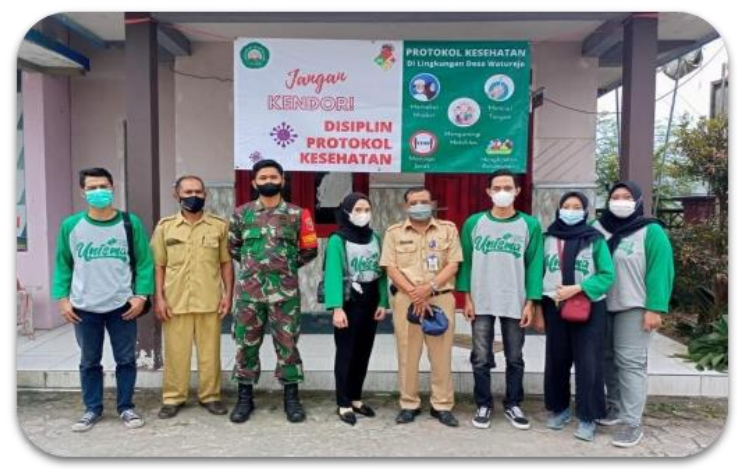

Gambar 6. Pemasangan Banner di Dusun Sumbergondo

(Sumber: Dok. KSM-Tematik Kelompok 07) 


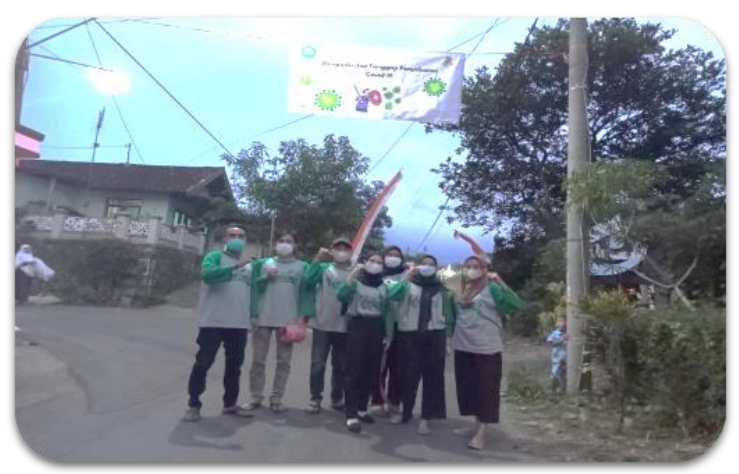

Gambar 7. Pemasangan Banner di Balai Desa Waturejo

(Sumber: Dok. KSM-Tematik Kelompok 07)

\section{KESIMPULAN}

Pandemi COVID-19 ini telah menyebabkan masalah serius pada dunia kesehatan global yang berdampak besar terhadap sudut pandang orang menginterpretasikan dunia dalam kegiatan sehari-hari krisis kesehatan global yang berdampak pada kegiatan kehidupan sehari-hari. Upaya pemerintah dalam pencegahan penyebaran virus COVID-19 di Indonesia yakni pemberlakuan pembatasan sosial dan imbauan penerapan Protokol Kesehatan 5M, yaitu memakai masker, mencucui tangan, menjaga jarak, menghindari kerumunan, serta mengurangi mobilitas.

Beberapa masyarakat di Desa Waturejo, Kecamatan Ngantang, Kabupaten Malang kurang peduli pada penerapan Protokol Kesehatan dan penerapan hidup sehat. Kurangnya kepedulian dan pelaksanaan Protokol Kesehatan ini akibat kuarangnya edukasi masyarakat akan pentingnya Protokol Kesehatan, oleh karena itu diperlukan sosialisasi mengenai pentingnya Protokol Kesehatan dan hidup sehat di tengah masa pandemi COVID-19 ini.

Sosialisasi di Desa Waturejo, Kecamatan Ngantang, Kabupaten Malang mengenai pentingnya penerapan protokol kesehatan dan hidup sehat di era pandemi COVID-19 dapat terlaksana dengan lancar dan dan disambut oleh antusiasme warga sekitar. Antusiasme warga nampak dari feedback yang diberikan, seperti warga yang fokus selama kegiatan penyampaian materi sosialisasi dan penyampaian pertanyaan dari warga kepada pemateri. Dari hal ini, dapat diindikasi bahwa warga sudah mulai memahami materi mengenai pentingnya penerapan Protokol Kesehatan dan hidup sehat di era pandemi COVID-19. Selain kegiatan sosialisasi kami juga mengadakan kegiatan pembagian masker serta hand sanitizer sebagai bentuk upaya mematuhi Protokol Kesehatan yang berlaku saat ini.

\section{UCAPAN TERIMA KASIH}

Ucapan terima kasih disampaikan kepada Lembaga Penelitian dan Pengabdian kepada Masyarakat (LPPM), Universitas Islam Malang yang telah memberikan kesempatan untuk dapat melakukan program pengabdian kepada masyarakat ini. Ucapan terima kasih juga disampaikan kepada warga dan segenap jajaran Pemerintah Desa Waturejo, Kecamatan Ngantang, Kabupaten Malang yang telah memberikan sambutan baik terhadap pelaksanaan berbagai kegiatan yang dilakukan.

\section{DAFTAR RUJUKAN}

Kemenkes RI. (2020). Pedoman dan Pencegahan Pengendalian Coronavirus Disease (Covid19). Jakarta: Kementrian Kesehatan RI. 
A, S. R., Trisiana, A., R, F. A., M, L. A., Syaiban, I., \& F, S. N. (2020). Menumbuhkan Kesadaran Masyarakat Indonesia untuk Memutus Rantai Penyebaran Wabah Covid-19. Global Citizen : Jurnal Ilmiah Kajian Pendidikan Kewarganegaraan, 61-62. doi:http://dx.doi.org/10.33061/jgz.v9i1.3889

Buana, D. R. (2020). Analisis Perilaku Masyarakat Indonesia dalam Menghadapi Pandemi Virus Corona (Covid-19) dan Kiat Menjaga Kesejahteraan Jiwa. Jurnal Sosial dan Budaya Syar- $i$.

Chen, N., Zhou, M., Dong, X., Qu, J., Gong, F., Han, Y., ... Zhang, L. (2020, January 30). Epidemiological and clinical characteristics of 99 cases of 2019 novel coronavirus pneumonia in Wuhan, China: a descriptive study. The Lancet. doi:https://doi.org/10.1016/S0140-6736(20)30211-7

Desiyanto, F. A., \& Djannah, S. N. (2013). Efektivitas Mencuci Tangan Menggunakan Cairan Pembersih Tangan Antiseptik (Hand Sanitizer) Terhadap Jumlah Angka Kuman. Jurnal Fakultas Kesehatan Masyarakat, 75-82. doi:http://dx.doi.org/10.12928/kesmas.v7i2.1041

Ilsan, M., Salim, M., \& Husain, T. K. (2020). Pelatihan Teknik Menyusun Laporan Keuangan Untuk UMKM Agribisnis. Jurnal Inovasi Hasil Pengabdian Masyarakat. doi:http://dx.doi.org/10.33474/jipemas.v3i2.5993

Prayitno, S. A., Pribadi, H. P., \& Ifadah, R. A. (2020, Agustus 21). Peran Serta dalam Melaksanakan Protokol Pencegahan Penyebaran Corona Virus Disease (COVID-19) Pada Masyarakat. DedikasiMU(Journal of Community Service). doi:http://dx.doi.org/10.30587/dedikasimu.v2i3.1657

Saputri, N. (2020). Terapkan Perilaku Hidup Bersih dan Sehat dengan Optimalkan Cuci Tangan dalam Upaya Pengendalian Infeksi. Jurnal Pelayanan dan Pengabdian Masyarakat, 46-50. doi:https://doi.org/10.52643/pamas.v4i1.784

KPCPEN. (2021). Situasi Covid-19 di Indonesia. Retrieved September 1, 2021, from Kementrian Komunikasi dan Informatika Republik Indonesia: https://covid19.go.id Wahyudi. (2020, Oktober 08). Pentingnya Menggunakan Masker Di Masa Pandemi. Retrieved from Rumah Sakit Umum Harapan Ibu: https://www.rsuharapanibu.co.id/pentingnya-menggunakan-masker-dimasapandemi/

WHO. (2020, Juni 5). Anjuran Mengenai Penggunaan Masker dalam Konteks COVID-19. Retrieved from World Health Organization: https://www.who.int/docs/defaultsource/searo/indonesia/covid19/anjuran-mengenai-penggunaan-masker-dalamkonteks-covid-19-june-20.pdf?sfvrsn=d1327a85_2 